Original research article

\title{
Children's violent deaths in families at risk - is there any possibility of prevention?
}

\author{
Adéla Lemrová ${ }^{1}$, Ivana Olecká ${ }^{2}$ *, Kateřina Ivanová ${ }^{1}$ \\ ${ }^{1}$ Palacký University Olomouc, Faculty of Medicine and Dentistry, Department of Public Health, Olomouc, Czech Republic \\ 2 Palacký University Olomouc, Sts Cyril and Methodius Faculty of Theology, Department of Christian Social Work, Olomouc, Czech Republic
}

\begin{abstract}
Objectives: The aim of the paper is to describe cases of violent death in children up to five years of age, where the abuse of addictive substances by their mother or other caregiver was detected or could have been presumed. Based on the results, the aim is to discuss the possibilities of preventive protection of children under 5 years in families at risk.

Theoretical base: A problematic lifestyle in childcare decreases the quality of care and can lead to the death of the child. Effective measures are especially necessary for children from families with risky behavior.

Methods: Retrospective analysis of autopsy files (at 2 forensic medicine departments) of children under 5 years of age who died suddenly, unexpectedly, and violently $(n=192)$ between 2007 and 2016.

Outcomes: There were 41 cases of violent deaths. In all cases there were families at risk and socially weak families. Control of the families by the Department of Social and Legal Protection of Children had been demonstrably conducted in 10 cases, which is $24 \%$ of the cases in the sample. Alcohol was present in $29 \%$ of cases, other illegal substances in $29 \%$ of cases. In total, the use of alcohol or illegal substances was found in $44 \%$ of violent child deaths.

Conclusions: Early detection of risks, dispensarization of endangered children and rehabilitation of their families is advisable preventively. The prevention of families with risky behavior and the protection of their children should take both paths - preventive and restrictive. The necessary condition for the protection of children is functional multidiscipline cooperation of all participating institutions.
\end{abstract}

Keywords: Child death; Family; Risky behavior; Socially weak family; Violence

\section{Introduction}

A child grows and develops in dependance on its environment; the chances of a child reaching adulthood depend on the social conditions (Kukla et al., 2016). The importance of family for the child's development is irreplaceable. Family has a crucial influence on the global development of the child's personality, especially in the earliest period of childhood, regarding the physical, mental, and social domains. Family is a micro-community, where the child learns behavior patterns, habits, customs, knowledge, and skills that are essential for his or her future life. It is necessary to point out the importance of a functional family which passes on the appropriate behavior patterns, values, and norms (Dunovský et al., 1995). The conditions of this period are influenced by social risk factors and protective factors. Social risk factors include the research-proven agents or conditions associated with an increasing probability of risky behavior in an individual. The presence of a social risk factor does not always mean the presence of risky behavior (Jessor, 2005).
One of the social risk factors is the use of addictive substances, which results in different levels of health and social risks, at the individual or population level. Addictologists, criminologists, lawyers, forensic psychologists, but also experts from other fields agree that substance abuse and its possible causal nexus - the relationship between cause and effect, "when the cause is every phenomenon without which another phenomenon would either not have occurred at all or would not have occurred in the way it occurred" (Šámal et al., 2012) with criminal activities are a very complicated and complex phenomenon that shows significant social harm (Scheinost et al., 2010).

The causal nexus between the substance abuse of the parent and the use of violence against children is not clear since the substance abuse alone cannot be the cause of violence against children. Although causality is not confirmed unambiguously in these cases, it is evident that any problematic use of higher doses of addictive substances while caring for a child is a socio-pathological phenomenon that can reduce the quality of such care (Olecká et al., 2019, Roškotová, 2015; Šlamberová, 2012; Šlamberová and Charousová, 2008; Zvonařová,

\footnotetext{
* Corresponding author: Ivana Olecká, Palacký University Olomouc, Sts Cyril and Methodius Faculty of Theology, Department of Christian Social Work, Na Hradě 5, 77900 Olomouc; e-mail: ivana.olecka@upol.cz

http://doi.org/10.32725/kont.2021.029

Submitted: 2021-02-05 • Accepted: 2021-05-19 • Prepublished online: 2021-06-16 
2012). Research shows that in combination with other social risk factors (unemployment, low socioeconomic status, poor social conditions, lack of interest in the child, etc.), it becomes a significant social risk factor of the child's death (Ivanová and Olecká, 2020). Health and social tertiary prevention focuses on the prevention of serious or permanent health or social harm as a result of risky behavior of families. "Prevention as a working method focuses on a wide range of human activities - the area of health, social, legal education, etc. Each area has its own particularities, but it is necessary to emphasize their interconnectedness." (Kukla et al., 2016)

Searches carried out in professional databases show that the issue of substance abuse and their prevention is a current topic (10,330,509 links found). The same is true of the topic of violence against children (1,406,079 links found). A more specific search for texts focusing on the issue of fatal violence against children under the influence of addictive substances yielded 1,194 references. When the texts without the keyword "death" were excluded, a total of 38 sources were found in the period 2010-2020. The professional academic texts found are mostly shifted to a higher level of generality and are directed mainly to recommendations concerning the protection of these children. Closest to the focus of the article were Donohue et al. (2019), Lane (2014) and Wu and Slesnick (2020). The situation is similar in the Czech context. Those who were closest to the topic in academic periodicals in the period 20102020 were Krrístek (2015), Nešpor (2018), Preslová (2012), Roškotová (2015), Šlamberová (2012), Zdražil (2016) and Zvonařová (2012). However, none of these texts (domestic or foreign) focuses specifically on the issue of violent deaths of children in connection with the use of addictive substances. Nevertheless, if we do not insist on reviewed texts, with the same keywords and in the same search period, we will find 193 results in e-resources, of which more than 30 sources depict specific child abuse by a mother under the influence of alcohol. The searches thus show the high topicality and social significance of the topic of violence against children under the influence of addictive substances.

Roškotová (2015: 37) and Zvonařová (2012) state that the number of children born in socially disadvantaged families is currently increasing, where despite their low-income the parents do not stop spending money on their own delights (alcohol, smoking) while they neglect the child's nutrition. As a General Practitioner for Children and Adolescents (PLDD), Roškotová (2015) states that it is always necessary to consider child abuse or maltreatment and, in case of suspicion, to report it to the Department of Social and Legal Protection of Children (OSPOD) in time, since the PLDD currently does not have any another possibility of intervention in such situations.

The Department of Social and Legal Protection of Children (OSPOD) is an institute that protects the rights of children.

When parents do not fulfill the obligations arising from their parental responsibility or when the child's life and health are endangered, the OSPOD is obliged to act. According to Act No. 359/1999 Coll., on the social and legal protection of children, the socio-legal protection measures need to be chosen so that they follow one after another and influence each other. When performing and implementing the measures, priority shall be given to those that ensure the proper upbringing and favorable development of the child in his or her family environment and, if this is not possible, in an alternative family environment.

The use of addictive substances by a parent is not in itself defined as a cause of danger for a child in the Act on the Social and Legal Protection of Children, and according to Křístek
(2015) it cannot even be objectively assessed. If a parent does not fail to care for a child as a result of substance abuse, he or she cannot be the subject of an "investigation" by the child welfare authorities. This only happens at the moment when it can be demonstrably inferred from non-performance, abuse or neglect of parental duties. Social workers should be able to detect and address such risky behavior. These skills should be acquired during the preparation for their profession and during the compulsory lifelong education (Křístek, 2015).

Effective measures are especially necessary for children from families with risky behavior. According to the WHO, these measures must go beyond the limits of the Ministry of Health and should involve wider civic initiatives, organizations, and institutions (WHO, 2001).

Medical examiners who encounter violent deaths of children in practice have to write detailed and accurate documents for a proper examination of the child's death and subsequent court proceedings. According to the document 'Health for All up to the 21st Century' (MoH CR, 2002), a retrospective study of the findings of forensic medicine departments in the Czech Republic is necessary, focusing on the murder of a newborn by its mother, as well as maltreatment, neglect, and sexual abuse. It can be assumed that the data on the number of children who died in connection with hostile conduct are underestimated (Olecká, 2018). In the past, pediatricians became the major fighters for children's rights when they noticed their serious injuries, which, however, could not be explained by accidental injury (Kukla et al., 2016).

The aim of the paper is to describe the cases in a group of children who died violently under the age of 5 , where the use of addictive substances by their mother or other caregiver was detected before their death or could have been presumed. Furthermore, the aim is also based on the results of a discussion on the possibilities of preventive protection of children under 5 years of age in families with risky behavior.

\section{Materials and methods}

The research method of choice was a retrospective analysis (covering 10 years, i.e. 2007-2016) of all autopsy files ( $n=192$ ) of children who died suddenly, unexpectedly, and violently before reaching 5 years of age, and who were autopsied at 2 departments of forensic medicine (department A and B) during the studied period. A group of cases was extracted from the set of all files where the death of the children was related to the hostile conduct of another person $(n=41)$. In this group, the frequency of the use of alcohol or illegal addictive substances by the caregiver and the presence of these substances in the child's body were determined. The frequency of the variables was recorded in a pre-structured sheet. Each autopsy protocol selected in this way was conceived as a case study, which consisted of a descriptive part and an exploratory part. The descriptive part described the results of the medical examination and autopsy of the deceased child and was statistically processed. In the exploratory part (the qualitative description of the situation), based on the conclusions of expert opinions, witness statements, police records, photo documentation, and other additional documents in the context of the data from the descriptive part, possible connections between the child's death and social risk factors of the mother were analyzed. The data were entered into semi-structured record sheets that were validated in the pre-research stage. A comparative and opinion discussion about each protocol took place within the research team. 
The research was subject to the approval of the Ethics Committee of the Olomouc University Hospital and the Faculty of Medicine of Palacký University. Before the onset of data collection, informed consent of the researchers was obtained. By signing the consent, the researchers confirmed that they would maintain the confidentiality of the sensitive data with which they would work. The analysis of the autopsy protocols of children who died under the age of 5 and obtaining extracts was performed only to the extent necessary for research.

\section{Results}

Within the studied period of 2007-2016, out of the total number of 192 cases of sudden, unexpected, and violent deaths of children, 41 cases were assumed to include hostile conduct.

The suspicion of hostile conduct was stated more frequently in department A (25\%) than in department B (19.7\%). The opposite is true with respect to the proportion of the proven presence of addictive substances. In half of the cases from department $B$, the presence of addictive substances was one of the identified circumstances of the child's death. In cases from department A, it was only in $33 \%$. However, it should be noted that the departments differ in the proportion of tested suspects. While in department A testing for addictive substances took place in only $27 \%$ of cases, in department B testing was more frequent - in $70 \%$ of cases.

Table 1 shows that there is a difference in the number of autopsied children who died suddenly, unexpectedly, and violently within 1 year of age and 5 years of age. There are twice as many children who died in infancy than children who died in this way at the age of $1-5$. In the case of the group of deceased infants under 1 year of age, hostile conduct was represented in $25 \%$ of cases, in the age group of $1-5$ it was $11 \%$ of cases. The group of children under the age of 1 is thus more than twice as often at risk of hostile conduct by the child's immediate caregiver. This phenomenon can be identified even more significantly in the case of substance abuse while caring for a child combined with the suspicion of hostile conduct. Addictive substances were detected more often in the group of parents of children who died before reaching the 1 st year (48\%). In case of hostile conduct in the age group of $1-5$, the presence of addictive substances was proven only in 1 case (16\%).

In families where the death of a child was related to the hostile conduct $(n=41)$, the OSPOD was demonstrably investigating 10 of these cases before the child's death, which represents $24 \%$ of the cases in the sample. In 6 of these cases (all including infants), in addition to the suspicion of hostile conduct, the presence of addictive substances was also proven ( $14 \%$ of the total number of cases of violent deaths) - see Table 2.

Table 1. Number of autopsied children according to their age (within the studied period of 2007-2016)

\begin{tabular}{lccc} 
& 0-1 year & 1 -5 years & $\begin{array}{c}\text { Total } \\
\text { 0-5 year }\end{array}$ \\
\hline $\begin{array}{l}\text { Total number of children } \\
\text { autopsied at both departments }\end{array}$ & 138 & 54 & 192 \\
\hline $\begin{array}{l}\text { Out of them - suspicion of hostile } \\
\text { conduct }\end{array}$ & 35 & 6 & 41 \\
\hline $\begin{array}{l}\text { Presence of addictive substance } \\
\text { together with hostile conduct }\end{array}$ & $\begin{array}{c}(25 \%) \\
(48 \%)\end{array}$ & $\begin{array}{c}11 \%) \\
(16 \%)\end{array}$ & $\begin{array}{c}(21 \%) \\
(44 \%)\end{array}$ \\
\hline
\end{tabular}

Table 2. Cases of diseased children from families under the supervision of OSPOD $(n=41)$ - within the studied period 2007-2016

$$
0-1 \text { year } 1-5 \text { years Total }
$$
$0-5$ year

\begin{tabular}{lccc}
\hline $\begin{array}{l}\text { Total number of children } \\
\text { autopsied at both departments }\end{array}$ & 35 & 6 & 41 \\
$\begin{array}{l}\text { Out of them - investigation of } \\
\begin{array}{l}\text { OSPOD in the family with hostile } \\
\text { conduct }\end{array}\end{array}$ & $\begin{array}{c}8 \\
(19 \%)\end{array}$ & $\begin{array}{c}2 \\
(5 \%)\end{array}$ & $\begin{array}{c}10 \\
(24 \%)\end{array}$ \\
$\begin{array}{l}\text { Investigation of OSPOD in the } \\
\text { family with hostile conduct and } \\
\text { at the same time with the proven } \\
\text { presence of addictive substance } \\
\text { from the total number }\end{array}$ & \begin{tabular}{c}
$(17 \%)$ \\
\hline
\end{tabular} & 0 & 6 \\
\hline
\end{tabular}

Table 3 depicts the amount and percentage of cases in which hostile conduct was suspected and at the same time the presence of addictive substances was proved in the parents or caregivers of deceased children or in children themselves. The effect of addictive substances was studied in 27 cases (Chart 1). Out of them, the influence of addictive substances was identified in 18 cases (44\%). Those who tested positive for both alcohol and illegal drugs are included in both categories simultaneously $(n=6)$. Alcohol was detected in $29 \%$ of parents and $12 \%$ of children. Illegal drugs and drug abuse were determined in $29 \%$ of parents and $3 \%$ of children. In 7 cases $(17 \%)$ the tests performed were negative, the influence of alcohol or illegal addictive substances was not proved.

When interpreting the data, it is necessary to consider not only the proportion between the amount of proved presence of addictive substances and the absence of these substances, but also the number of cases in which such information was not recorded for various reasons. Table 3 also shows that out of the total number of 41 cases of hostile conduct, the presence of alcohol was not analyzed in $42 \%$ of parents and in $29 \%$ of children. The presence of illegal addictive substances was not analyzed in parents in $47 \%$ of cases and in children in $34 \%$ of cases.

Chart 1 depicts the proportion between the non-performed and performed tests for addictive substances (alcohol and illegal addictive substances).

\begin{tabular}{|c|c|c|c|c|}
\hline & $\begin{array}{c}\text { Alcohol - } \\
\text { parents }\end{array}$ & $\begin{array}{c}\text { Illegal } \\
\text { addictive } \\
\text { substances } \\
\text { - parents }\end{array}$ & $\begin{array}{l}\text { Alcohol - } \\
\text { children }\end{array}$ & $\begin{array}{c}\text { Illegal } \\
\text { addictive } \\
\text { substances } \\
\text { - children }\end{array}$ \\
\hline Effect proved & $\begin{array}{c}12 \\
(29 \%)\end{array}$ & $\begin{array}{c}12 \\
(29 \%)\end{array}$ & $\begin{array}{c}5 \\
(12 \%)\end{array}$ & $\begin{array}{c}1 \\
(3 \%)\end{array}$ \\
\hline $\begin{array}{l}\text { Effect not } \\
\text { proved }\end{array}$ & $\begin{array}{c}12 \\
(29 \%)\end{array}$ & $\begin{array}{c}10 \\
24 \%)\end{array}$ & $\begin{array}{c}24 \\
(59 \%)\end{array}$ & $\begin{array}{c}26 \\
(63 \%)\end{array}$ \\
\hline $\begin{array}{l}\text { Effect not } \\
\text { analyzed }\end{array}$ & $\begin{array}{c}17 \\
(42 \%)\end{array}$ & $\begin{array}{c}19 \\
(47 \%)\end{array}$ & $\begin{array}{c}12 \\
(29 \%)\end{array}$ & $\begin{array}{c}14 \\
(34 \%)\end{array}$ \\
\hline Total & $\begin{array}{c}41 \\
(100 \%)\end{array}$ & $\begin{array}{c}41 \\
(100 \%)\end{array}$ & $\begin{array}{c}41 \\
(100 \%)\end{array}$ & $\begin{array}{c}41 \\
(100 \%)\end{array}$ \\
\hline
\end{tabular}




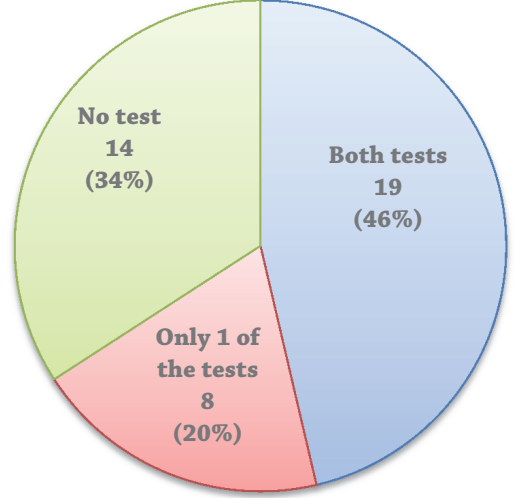

Chart 1. Performed tests on the addictive substances (within the studied period 2007-2016)
In $46 \%$ of cases $(n=19)$, tests for alcohol as well as illegal substances were performed at the same time, either with a positive or negative result. In 8 cases, only one of the tests was performed, either on alcohol $(n=5)$ or on illegal substances $(n=3)$. In 14 cases (34\%), the presence of addictive substances was not analyzed by any method, not even in the body of the parent or a suspect. The information on the total number of cases of substance abuse before death can therefore be considered underestimated. Alcohol or illegal substances (or both) were certainly found in the blood of caregivers in $44 \%$ of all violent deaths of children. On the other hand, in $17 \%$ of cases the caregiver was not under the influence of any addictive substance.

The set of statistical data is supplemented by illustrative case studies (Table 4).

Table 4. Case studies

Medical information Family and the cause of death

1.

Adam

(5 years, small, low weight, bad teeth, glasses)

\section{Swelling of brain,} intracranial injuries, fresh and old injuries all over the body, blunt violence of medium and higher intensity (head, buttocks, legs)

\section{Barbora}

(9 months,

Adam's

sister, dies 5

months after

her brother's

death)

\section{Strangled}

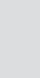

Mother 28 years, maternity leave, stepfather - driver 29 years, sister 4 months. Old house under reconstruction, mess. Mother beaten by the boy's biological father. The boy went to kindergarten. He was in touch with his grandparents. Changed behavior of the boy after his sister was born, jealousy, the boy was often punished (spanked by hand or wooden spoon).

The file suggests that the mother began seeing another man and her partner could not bear it.
2.

Dalibor

(3 months) 
In the first case (and second - regarding the sister) it is evident that the OSPOD was contacted by the pediatrician and that it was a problematic family. The children in this family died without any help from their surroundings. In the record (photocopy of PLDD's medical records) of the first case, only 1 phone call back to PLDD is recorded to check the situation by the OSPOD, almost 9 months after reporting the neglect of care (in the case of a beaten 5-year-old boy). It can also be assumed that the family may have "disappeared from the system" at the time of moving. However, after the death of the 5-year-old boy, his stepfather was investigated for the crime of injury. The question therefore is whether and how the family was supervised and whether the sister had to die as a result of the influence of alcohol. Also striking is the absence of any reaction from the social environment (kindergarten, grandparents, neighbors, ...).

In the third case, the mother smoked and consumed alcohol during pregnancy and breastfeeding, and did not undergo any medical examinations during pregnancy. There was considerable negligence in relation to childcare, her first child lived with its father, we have no information about the second child. She did not hesitate to leave the child in the care of a stranger under the influence of alcohol during her visit to the bar. Her sense of responsibility was also problematic, she reported her absence from the shelter at $10 \mathrm{pm}$ (according to testimony, she was forced to do so, she probably wouldn't have done it herself, even at the cost of complications that it would bring to her). The question is whether the staff in the shelter could or should have known or knew about the mother's addiction and how the child was protected in this case (Lemrová et al., 2017).

\section{Discussion}

The research confirmed that a necessary condition for the prevention of violent conduct against children under 5 years of age is the cooperation of all interested institutions: Police of the Czech Republic, OSPOD, doctors (primarily pediatricians, medical examiners, ambulance physicians), educational organizations etc. The low record of cases of behavior under the influence of addictive substances indicates the need for coordinated cooperation with the police and addictology services.

The information validity regarding the cases is reduced by the fact that in the analyzed autopsy files (the documentation created by health professionals) it is more likely to find data in cases where the doctor was active (i.e. reported the problematic family situation); less information is available on situations where the action was taken by OSPOD and other organizations failed to respond adequately. The situation could benefit from a unified diagnostic system across the forensic medicine departments (Olecká, 2018).

According to 'Health for All up to the 21st Century' (MoH $C R, 2002)$, there is a lack of mutual information and procedure coordination of various experts and non-governmental organizations for the implementation of interdisciplinary cooperation. Often, there is indiscretion in the cooperation of social workers, the police, educators, and health professionals during the subsequent investigation by the law enforcement authorities. There is a significant lack of well-trained psychologists and psychotherapists in this area. Twelve years later, the new WHO Health 2020 program (MoH CR, 2014) again states that there are no comprehensive data on violence against children in the Czech Republic available. In the area of child maltreatment, abuse, and neglect, there are still shortcomings with respect to the interdisciplinary cooperation of doctors, psycho- logists, the police, the social and legal protection department for children, etc. Research has shown that a quarter of deaths (10 cases - Table 2), where the child's death was related to the hostile conduct of another person, represented families where before the death of the child there was already a suspicion of inappropriate conditions for healthy development of the individual and the family was investigated by OSPOD. However, the child's death could not be prevented.

Social workers are often not informed that the client is already in touch with another social service and therefore act in an uncoordinated manner. If the child is not in any danger, they can only be informed about the client in general or not at all. In case of sharing information beyond the permitted scope, the social worker risks losing the job. Another problem is the possible mutual distrust between the social workers (Zdražil, 2016).

OSPOD is highly dependent on external information in its activities. Doctors and educational facilities are legally bound to report suspected abuse and neglect to OSPOD. Based on the cases known through media coverage, the public is often silent and does not report the child abuse or neglect. In case the family moves, there is no obligation to report oneself at the place of new residence; such a family then "drops out" of the system.

Dunovsky et al. (1995) also talk about the so-called secondary victimization, which is caused by the inappropriate and insensitive approach of the authorities and institutions when dealing with the child abuse. Such behavior can be caused, for example, by the uncoordinated approach of individual institutions, repeated investigation of the child and family members, etc.

However, any social climate change is necessarily linked to enlightenment and education. What can be used for instance are the awareness-raising campaigns aimed at zero tolerance of all manifestations of domestic violence and related other risk phenomena, such as alcohol and substance abuse or gambling. As a part of secondary prevention, what is needed is the early detection of risks and prevention of their further impact by dispensing the endangered children and rehabilitating their families or other social environments. This can be achieved through regular monitoring based on screening. The purpose of tertiary prevention is to prevent further development of trauma, irreversible consequences, complications, but also systematic violence, which can be a source of poly-victimization of children. Abused or neglected children in many cases become abusive or neglecting parents (Dunovský et al., 1995).

According to the Convention on the Rights of the Child (Communication No. 104/1991 Coll.), for a child to achieve full and harmonious development of personality in adulthood, the child must grow up in a family environment in an atmosphere of happiness, love and understanding. The family is a place where it is possible to fulfill individuality and community, and its mission should be to enable a person to live a full and rich life (Pospíšil, 2000). In the professional literature we can find various designations of families who can be provided with support from social workers. These are terms such as problem family, dysfunctional family, multi-problem family, family in danger, family at risk etc. What these families have in common is the fact that there is a problem, something that hinders the family in its normal and proper functioning. Knausová (2011) describes these families as families at risk. According to $\mathrm{Ma}-$ toušek and Pazlarová (2010), the problems most often faced by families include the lack of funds to cover basic physiological needs, housing problems, inability to manage the financial budget, inability to set spending priorities, non-payment of rent, numerous unpaid loans, imminent seizure of property, 
lack of activity in finding a job, alcohol- or drug addiction of one or more family members, problems with childcare and the fulfillment of one's parental role, maltreatment or abuse of certain family members, and others.

In the Czech Republic, there are currently no aggregate valid data on the violence against children. Pilot studies provide inaccurate and often misleading data. Currently, the prevention of violence against children is addressed in a number of documents, such as the following: National Concept of Family Policy (MoLSA CR, 2017), National Strategy for the Protection of Children's Rights ("Right to Childhood") (MoLSA CR, 2012), The National Plan for Combating Commercial Sexual Exploitation of Children (MoLSA CR, 2006), and the National Strategy for the Prevention of Violence against Children in the Czech Republic for the Period 2008-2018 (Office of the Government of the Czech Republic, 2008). The first major goal of the latter document is to support the development of parental competencies, that are based on the support of positive parenting and the parents' understanding of the basic needs and rights of children (Office of the Government of the Czech Republic, 2008).

Child abuse is condemned in all societies and cultures (Možný 2008). A common feature of all cases of suspected hostile conduct is the low health literacy of the mother, which results in the reduced ability to care for the child as well as worsened health of the children. Manifestations of reduced health literacy were identified most often in the form of neglecting preventive check-ups of the child by a pediatrician, leaving the child unattended, and failing to call for medical help (Olecká, 2018).

In accordance with the document Strategies for Preventing Child Maltreatment by Developmental Stage and Level of Intervention (WHO, 2007: 10), it would be appropriate to launch programs to support parental skills, including visits to the problematic families. The program of home visits according to the Hana Like Home Visitor is also mentioned by Mazúchová (2012). It is a program designed to intervene and prevent and provide follow-up services for pregnant women who have been identified as having a high risk of abuse and neglect of their children. Lane (2014) recommends using the already developed risk identification tools (e.g. SPARK - Structured Problem Analysis of Raising Kids or SEEK - Safe Environment for Every Kid).

Social prevention focusing on families at risk should follow both paths - preventive and restrictive. A coordinated, multidiscipline, and continuously evaluated approach could protect the lives of endangered children. The improvement of the situation should be monitored by a research of this type. It would be desirable to involve the forensic medicine departments (physicians) and experts in the field of social protection of the child more in the process of ascertaining the circumstances of the death of children on the spot, since they can get a quality picture of the situation and evaluate whether poor childcare could have contributed to the child's death. If, based on the results of the autopsy, the medical examiner states that the death was natural, the law enforcement authorities have more limited options to investigate whether it was a planned offense, and the culprit remains unpunished. A child protection expert could assess the situation on the spot and recommend an intervention to the family to prevent possible abuse of other children in the family or their death.

Problematic substance abuse by parents potentiates the risk of child abuse and hostile treatment of children with fatal consequences. For this reason, it appears important to add a recommendation of addictology services. It would be appropri- ate (if a problematic link between the mother and psychoactive substances is found) for the doctor (gynecologist) to assist in connecting the family to addictology services as soon as possible, ideally during pregnancy. PLDD in particular could play an important role in the prevention. It should be considered to reintroduce the visits of the pediatrician in the mothers' home during her puerperium and to increase the control of problematic and dysfunctional families. These visits are not only aimed at control and supervision, but above all they reduce the risks arising from the lower health literacy of the mother. To reduce the stigma of some families, it is appropriate to introduce this screening nationwide. The pediatrician who visits the family and sees the parents in their natural environment will be able in a better way to detect any potential risk factors. The crucial condition is that PLDDs can analyze the risks in a timely manner and respond properly. For example, they could be the key experts in tackling the problem of "dropping out" of the system (see Discussion), which could be captured through the information in the pediatrician's medical records. If a child with a history of a problematic or dysfunctional family be taken into care by a doctor, he or she should be able to contact the OSPOD. The same procedure can be proposed even if the parents do not provide the medical documentation and it is not possible to obtain it in another way. It would then be appropriate to base the cooperation on mutual communication between these entities. The problem with the registration of cases can also be traced in the forensic medicine practice, where it is practically impossible to determine whether a child is not a sibling of a child who died under similar circumstances.

The last recommendation concerns the cooperation of OSPOD, PLDD, and gynecologists with addictology services. When detecting the addiction of the mother as part of prenatal screening during pregnancy, gynecologists should automatically refer the mother to addictology services. These services should have recommended procedures available for the prevention of risky behavior of mothers. If the problematic substance use is not detected by a gynecologist, it should be passed to PLDD or OSPOD.

\section{Conclusions}

A family that does not fulfill its functions to varying degrees may represent fatal consequences for a child's health and life. If, despite the unfavorable social conditions, an abused child lives to adulthood, there is a risk of a repetition of the patterns of behavior he or she brings from his or her original family, and the previously abused child may start abusing as well. Early rehabilitation of the family can thus help to step out of the spiral of generationally repeated abuse and neglect of children. Hostile behavior toward children can be prevented, in particular, by targeted prevention of families with risky behavior. It is possible to consider two ways: preventive and repressive. Both have the potential, under certain circumstances, to help protect not only the health but also the lives of children. The preventive way would mean strengthening the role of OSPOD in the prevention process and improving its media image; many options are in the hands of pediatricians. Repressive measures by the police and forensic institutions should, through the restrictions, go back to preventive measures. Another tool for prevention is a targeted support of the social climate that will not tolerate any acts of violence. The indifference of the social environment in many cases appears to be a critical point at which any help for a child fails. The authors of the article consider a multidisciplinary cooperation between all 
the above-mentioned components to be the crucial preventive measure. A coordinated, multidisciplinary, and continuously evaluated approach could protect the lives of children at risk.

\section{Ethical aspects and conflict of interests}

The authors have no conflict of interests to declare.

\section{Acknowledgements}

The paper was supported by a specific university research project IGA of Palacký University in Olomouc no. IGA LF_2018_023 (RVO 61989592) and the Palacký University in Olomouc research project no. IGA_LF_2021_026.

\section{Násilná úmrtí dětí v rodinách s rizikovým chováním - existuje možnost prevence?}

\section{Souhrn}

Cíl: Cílem příspěvku je na souboru dětí násilně zemřelých do 5 let popsat případy, u kterých bylo před smrtí zjištěno nebo mohlo být předpokládáno užití návykových látek jejich matkou či jiným pečovatelem. V návaznosti na výsledky diskutovat možnosti preventivní ochrany dětí do 5 let v rodinách s rizikovým chováním.

Teoretická východiska: Problémový životní styl při péči o dítě snižuje kvalitu této péče a může vést až ke smrti dítěte. Účinná opatření jsou nezbytná zvláště u dětí z rodin s rizikovým chováním.

Metody: Retrospektivní analýza všech pitevních spisů $(n=192)$ dětí zemřelých náhle, neočekávaně a násilně do 5 let pitvaných na 2 pracovištích soudního lékařství v letech 2007-2016.

Výsledky: Případů hostilního jednání bylo 41 . Ve všech případech šlo o rodiny s rizikovým chováním a sociálně slabší rodiny. Prokazatelně probíhalo před smrtí dítěte šetření OSPOD v 10 případech, což činí $24 \%$ případů ze souboru. Alkohol byl přítomen ve 29 \% případů, nelegální návykové látky byly zjištěny ve 29 \% případů. Celkem bylo zjištěno užívání alkoholu nebo nelegálních látek ve $44 \%$ případů násilných úmrtí dětí.

Závěr: Preventivně je žádoucí včasná detekce rizik, dispenzarizace ohrožených dětí a sanace jejich rodin. Prevence rodin s rizikovým chováním a ochrana jejich dětí by se měla ubírat preventivní i restriktivní cestou. Podmínkou je fungující multidisciplinární spolupráce všech zúčastněních institucí.

Klíčová slova: násilí; rizikové chování; rodina; sociálně slabá rodina; úmrtí dítěte

\section{References}

1. Act No. 359/1999 Coll., o sociálně-právní ochraně dětí. In: Sbírka zákonů České republiky, částka 111/1999.

2. Communication No. 104/1991 Coll. - Sdělení č. 104/1991 Sb., federálního ministerstva zahraničních věcí o sjednání Úmluvy o právech dítěte. In: Sbírka zákonů České republiky, částka 22/1991.

3. Donohue B, Plant CP, Chow G, Schubert K, Bradshaw K, Cappellano JU, Allen DN (2019). Contribution of Illicit/NonPrescribed Marijuana and Hard-Drug Use to Child-Abuse and Neglect Potential while Considering Social Desirability. Br J Soc Work 49(1): 77-95. DOI: 10.1093/bjsw/bcy027.

4. Dunovský J, Dytrych Z, Matějček Z, et al. (1995). Týrané, zneužívané a zanedbávané dítě. Praha: Grada Publishing, 245 p.

5. Ivanová K, Olecká I (2020). Kumulativní efekt sociálních rizikových faktorů u kojenců zemřelých udušením. Čes-slov Pediat 75(8): 458-464.

6. Jessor R (2005). Foreword. In: Bonino S, Cattelino E, Ciairano S. Adolescents and Risk: Behaviors, Functions, and Protective Factors. New York: Springer, pp. v-vi.

7. Knausová I (2011). Teorie a praxe sanace rodiny v českém prostředí - kvalitativní sonda do terénní práce s ohroženou rodinou v současnosti. Sociální práce / Sociální práca 11(1): 68-73.

8. Kř́istek A (2015). Předpoklady, účel a limity sociální práce s cílovou skupinou rodičů užívajících návykové látky (1.) Právo a rodina (5): 6-10. [online] [cit. 2020-03-19]. Available from: http://archiv.streetwork.cz/images/stories/Kluby/ StreetWorkCZ/wk/par-5_kristek.pdf

9. Kukla L, et al. (2016). Sociální a preventivní pediatrie v současném pojetí. Praha: Grada Publishing, $456 \mathrm{p}$.

10. Lane WG (2014). Prevention of child maltreatment. Pediatr Clin North Am 61(5): 873-888. DOI: 10.1016/j.pcl.2014.06.002.

11. Lemrová A, Ivanová K, Olecká I (2017). Je tíživá životní situace motivem pro vraždu dítěte? In: Večerka K (Ed). Kontexty sociálních deviací. Česká sociologická společnost, sborník z konference sekce sociální patologie; 19.-21. 4. 2017; Svratka. Praha; Výzkumný ústav kriminalistiky, pp. 180-187.

12. Matoušek O, Pazlarová H (2010). Hodnocení ohroženého dítěte a rodiny $-v$ kontextu plánované péče. Praha: Portál.

13. Mazúchová L (2012). Preventívne programy CAN syndrómu u detí. Kontakt 14(3): 269-275. DOI: 10.32725/kont.2012.030.

14. Možný I (2008). Rodina a společnost. 2nd, revised ed. Praha: Sociologické nakladatelství. Studijní texty (Sociologické nakladatelství), $312 \mathrm{p}$.

15. MoH - Ministry of Health of the Czech Republic (2002). Zdraví pro všechny v 21. století. [online] [cit. 2020-08-19]. Available from: https://www.mzcr.cz/zdravi-pro-vsechny-v-21-stoleti/

16. MoH - Ministry of Health of the Czech Republic (2014). Zdraví 2020 - Národní strategie ochrany a podpory zdraví a prevence nemocí. [online] [cit. 2020-08-19]. Available from: https://www. mzcr.cz/zdravi-2020-narodni-strategie-ochrany-a-podporyzdravi-a-prevence-nemoci-2/

17. MoLSA CR - Ministry of Labour and Social Affairs of the Czech Republic (2006). Národní plán boje proti komerčnímu sexuálnímu zneužívání dětí 2006-2008. [online] [cit. 2019-0802]. Available from: www.mvcr.cz/soubor/npkszd-2006-2008fin-pdf.aspx

18. MoLSA CR - Ministry of Labour and Social Affairs of the Czech Republic (2012). Národní strategie ochrany práv dětí („Právo na dětství'). [online] [cit: 2019-08-02]. Available from: https:// www.mpsv.cz/files/clanky/14309/NSOPD.pdf

19. MoLSA CR - Ministry of Labour and Social Affairs of the Czech Republic (2017). Národní koncepce rodinné politiky. Praha: MPSV. [online] [2019-08-02]. Available from: https://www. mpsv.cz/files/clanky/31574/Koncepce_rodinne_politiky.pdf

20. Nešpor K (2018). Alkohol a jiné návykové látky u žen Identifikace a časná intervence. [online] [cit. 2019-06-19]. Available from: http://www.alkoholik.cz/zavislost/ke-stazeni/ online-knihy/category/1-online-knihy.html

21. Office of the Government of the Czech Republic (2008) Národní strategie prevence násilí na dětech v ČR na období 2008-2018. [online] [2019-06-19]. Available from: https:// www.vlada.cz/cz/ppov/rlp/dokumenty/strategie-prevencenasili-na-detech/strategie-prevence-nasili-na-detech-59898/ 
22. Olecká I (2018). Sociální rizikové faktory matek dětí zemřelých náhle, neočekávaně a násilně do jednoho roku života [Social Risk Factors of Mothers of Children Up to One Year of Age Who Died Suddenly, Unexpectedly and Violently]. Dissertation. Univerzita Palackého v Olomouci, Lékařská fakulta.

23. Olecká I, Přecechtěl P, Skarupská H (2019). Abúzus alkoholu pečujících osob jako rizikový faktor smrti dětí do pěti let: Limity statistických přehledů kriminality. Sociální Pedagogika 7(1): 8-20. DOI: 10.7441/soced.2019.07.01.01.

24. Pospíšil J (2000). Principy rodiny a jejich historické kořeny. Paidagogos 2000(1)

25. Preslová I (2012). Dopady alkoholismu rodičů na děti. [online] [cit. 2019-03-01]. Available from: https://www.sancedetem.cz/ cs/hledam-pomoc/rodina-v-problemove-situaci/rodice-jsouzavisli/dopady-alkoholismu-rodicu-na-deti.shtml

26. Roškotová O (2015). Praktický lékař pro děti a dorost (PLDD) a jeho možnosti poskytování služeb dětskému a dorostovému pacientovi. Česko-slovenská pediatrie 70(1): 36-39.

27. Scheinost M, et al. (2010). Kriminalita očima kriminologů. [online] [cit. 2020-03-19]. Available from: http://www.ok.cz/ iksp/docs/371.pdf

28. Šámal P, et al. (2012). Trestní zákoník: komentář. 2nd ed. Praha: C. H. Beck.

29. Šlamberová R (2012). Drugs in Pregnancy: The Effects on Mother and Her Progeny. Physiol Res 61(Suppl. 1): S123-135. DOI: 10.33549 /physiolres.932357.

30. Šlamberová R, Charousová P (2008). Metamfetamin - droga těhotných závislých žen. Československá fyziologie 57(1):
15-23. [online] [cit. 2018-09-16]. Available from: http://www. tigis.cz/images/stories/Fyziologie/2008/1_08/05_Slamberova_ Cs.Fyziologie_1_08.pdf

31. WHO (2001). Zdraví 21: osnova programu Zdraví pro všechny v evropském regionu Světové zdravotnické organizace.

32. WHO (2007). Preventing Child Maltreatment in Europe: a Public Health Approach. Policy Briefing. [online] [cit. 202003-19]. Available from: http://www.euro.who.int/en/healthtopics/disease-prevention/violence-and-injuries/publications/ pre-2009/preventing-child-maltreatment-in-europe-a-publichealth-approach.-policy-briefing

33. Wu Q, Slesnick N (2020). Substance abusing mothers with a history of childhood abuse and their children's depressive symptoms: the efficacy of family therapy. J Marital Fam Ther 46(1): 81-94. DOI: 10.1111/jmft.12364.

34. Zdražil J (2016). Potřeby klientů OSPOD Otrokovice, Terénní služby pro rodiny s dětmi a Nového domova Otrokovice v roce 2016. Výzkumná sonda Otrokovice: Komunitní plánování sociálních služeb. [online] [cit. 2019-06-02]. Available from: otrokovice.cz/assets/File.ashx?id_org=11673\&id_ dokumenty $=8581$

35. Zvonařová M (2012). Příklady problémů ve vztazích mezi generacemi $v$ rodinách s týraným, zneužívaným nebo zanedbávaným dítětem. Sociální práce / Sociálna práca 12(4): 7-10. [online] [cit. 2019-06-02]. Available from: https://socialniprace.cz/priklady-problemu-ve-vztazichmezi-generacemi-v-rodinach-s-tyranym-zneuzivanym-nebozanedbavanym-ditetem/ 